\title{
Effect of Climate-Adapted Forest Management on Carbon Pools and Greenhouse Gas Emissions
}

\author{
Robert Jandl • Jürgen Bauhus • Andreas Bolte • \\ Andreas Schindlbacher • Silvio Schüler
}

Published online: 28 January 2015

(C) Springer International Publishing AG 2015

\begin{abstract}
Adaptation to climate change is a current priority in forest management. Some of the suggested measures aim at maintaining the economic viability of timber production, others at maximizing social benefits, and others are recommended to increase the size of the carbon pool in forests. All of them need to be valid for a broad range of site conditions in order to capture the major part of the uncertainty of climate change. Discontinuing forest management with the intention of maximizing the carbon pool in the ecosystem is unrealistic in regions where a timber market needs to be supplied. Adaptive measures can be broadly classified into those that increase the heterogeneity of forests and those that affect the exposure of forests to disturbances. Increasing the heterogeneity distributes the risk imposed by climate change on more elements with different vulnerabilities. Typically, the tree species composition is scrutinized and new tree species or more suitable
\end{abstract}

This article is part of the Topical Collection on Climate Change and Carbon Sequestration

R. Jandl $(\bowtie) \cdot$ A. Schindlbacher $\cdot$ S. Schüler

Austrian Research Centre for Forests, Seckendorff-Gudent-Weg 8,

1131 Vienna, Austria

e-mail: Robert.jandl@bfw.gv.at

A. Schindlbacher

e-mail: andreas.schindlbacher@bfw.gv.at

S. Schüler

e-mail: silvio.schueler@bfw.gv.at

J. Bauhus

Department of Silviculture, University of Freiburg, Tennenbacherstr.

4, Friedrichstr 39, 79098 Freiburg, Germany

e-mail: juergen.bauhus@waldbau.uni-freiburg.de

\section{A. Bolte}

Thünen Institute, Institute of Forest Ecosystems, Alfred-Möller-Straße 1, Haus 41/42, 16225 Eberswalde, Germany

e-mail: andreas.bolte@ti.bund.de members from within the genetic spectrum of the respective tree species are favored. Managing the disturbance regime includes the modification of the stand structure and density to envisioned future needs and provisions against abiotic and biotic stressors. Adaptation measures such as the introduction of tree species that are more tolerant to future climate conditions into currently highly productive forests in most cases negatively affect the carbon sink capacity in the short-term. The same holds true for an adaptive decrease in stand density. Over the long run, however, increased resistance and resilience against changing environmental conditions and alternating disturbance regimes can substantially reduce the risk of carbon loss from managed forests which might reach unforeseen amounts if no adaptation measures are undertaken. The implementation of new forms of forest management depends not only on foresters, but also on the needs that society expresses towards the provision of forest products and ecosystem services.

Keywords Adapted forest management - Temperate forests . Climate change $\cdot$ Carbon storage $\cdot$ GHG emissions

\section{Introduction}

The term adaptive management was coined by Holling [69] and describes the development of useful land management strategies in an iterative process of interaction between scientists, practitioners, and stake holders. A challenge of the approach is finding a common terminology among these groups and agreeing on a transparent procedure of decision making. As long as scientists express widely controversial thoughts on climate change effects on forest and potential adaptation measures, forest practitioners are rather reluctant to adapt forest 
management. Existing scientific knowledge needs to be summarized and communicated to forest practitioners in order to maintain a continuous exchange of experiences derived from successful case studies.

Adaptive forest management (AFM) can have different objectives such as ensuring biodiversity, provision of drinking water, protection against natural hazards, or increasing timber production. Here, we focus on the effects of AFM measures on the dynamics of greenhouse gas emissions and carbon sinks. Forests are the major terrestrial carbon sink and currently absorb about $27 \%$ of the annual fossil fuel emissions worldwide. Without these natural sinks, the rate of $\mathrm{CO}_{2}$ increase in the atmosphere would be substantially higher. But this forest sink depends on the current condition of forested land and is related to unique processes. These processes include afforestation of some 40 million ha in China and the recovery of European temperate and boreal forest following the transformation to forests of large tracts of Eastern European and Russian agricultural land following abandonment. It is unlikely that this kind of large-scale forest development of spare agricultural land could happen again. That will make it more difficult to maintain the current ecosystem sink into the future [1].

On the optimistic side is a scenario where, in a warmer world, trees will grow faster, utilize longer growing seasons, flourish in areas where they had never before grown, sequester more carbon, and thus increase the carbon sink. The more pessimistic view is that warmer temperatures will result in increasing tree mortality owing to disturbances such as forest fires, storms, insect depredation, and droughts stress as well as more peatland decomposition, thawing permafrost, and the transformation of terrestrial ecosystems into carbon sources [2]. In the long-term, productive forest ecosystems may be replaced by less productive ones [3]. The productivity enhancement due to longer growing seasons and the adverse effect of droughts during the growing season have been described for many regions [4-7]. Only a part of the sink strength of forest ecosystems is linked to insightful forms of adaptive management. In Europe, the difference between wood removed in annual tree harvests and wood increment have led to a strong carbon sink for several decades even without specific AFM concepts. Forest soils were also a net sink [8], although gains were offset by losses from agricultural soils and peatland $[9,10]$.

Several national studies have investigated forest management scenarios in order to find an optimal solution for the balance between utilization of the forest resources for timber, fiber, and bioenergy, and the conservation of forests for the sake of accruing a large stock of carbon in biomass and soils [11-14]. Generally, the studies highlight the substantial role of long-lived wood products substituting for energy-intensive materials such as steel or concrete for the mitigation of climate change effects. The role of forest conservation for the accumulation of carbon stocks is controversial. The undisputed large carbon stocks in old-growth forests need to be balanced against the higher risk of mature forests to stand replacing disturbances affecting tall and old forest stands and their decreasing carbon sequestration capacities [15-19]. Therefore, old-growth forest with high carbon stocks can develop only in some parts of the landscape, less exposed to and less affected by severe disturbances [20, 21]. Moreover, the mere evaluation of the standing stock of carbon is a limited perspective. Job opportunities generated by forestry are a vital part of the rural economy, and some ecosystem services are optimized by forest management. With a growing population worldwide, the demand for wood is expected to increase up to $50 \%$ until 2030 [68], making on overall increase of untouched old-growth forests rather unlikely. Furthermore, the consideration of wood products for material and energy substitution as well as product storage obviously overrules the climate change mitigation potential of unmanaged forests [22-25].

There are substantial regional differences in the current role of forests with respect to climate change mitigation. This text summarizes experiences mostly from Central Europe where climate change is presently seen both as an opportunity and a challenge for forestry [26]. Although many forest stands have been established as plantations, the characteristics of native forests are obtained during the 100-year rotation period. The well-documented active forest management comprising species selection, thinning operations is a suitable basis for the evaluation of AFM measures to cope with unfavorable consequences of climate change. We review the options of forest owners intending to pursue the profitable provision of timber production within the legal framework ensuring the provision of societal functions of forest ecosystems. The present form of continuous cover forestry in Central Europe is already deemed adequate for the long-term sequestration of $\mathrm{CO}_{2}$ in the biomass and in soils [24, 27, 28]. In other regions, novel forms of forest management without historical precedence may need to be implemented but this adds uncertainty to forest management.

\section{Creating Heterogeneity}

The pressure from climate change can be mitigated by creating variation and heterogeneity in forest stands, analog to the portfolio theory in economics [29]. The idea is that in heterogeneous ecosystems and diverse forest landscapes, the risk exerted by environmental abiotic or biotic stress or disturbance agents is distributed to different species, tree dimensions, or different stand structures that are vulnerable to different degrees. Moreover, species mixtures and structural heterogeneity may increase stress resistance and adaptive 
capacity due to facilitation by complementary or asynchronous use of space and growth resources [30, 31].

\section{Tree Species Selection}

Responding to the challenges of climate change by replacing tree species with foreseeable difficulties with tolerant and equally or more productive ones is an option that is available only during a short time window of the lifetime of a forest. For economic reasons, it requires that the original mature stand is harvested and the site is afforested. In silvicultural systems, where natural regeneration of trees is favored, it is questionable whether novel tree species will regenerate and develop in a forestry-relevant density and spatial pattern, in particular when these are light-demanding species [32]. An example is the replacement of pure Norway spruce (Picea abies) forests in the Foothills of the Alps. Spruce is more vulnerable to drought than beech (Fagus sylvatica) and oak (Quercus petrea). A mixed stands with all three species is considered ecologically stable and reasonably productive [33]. However, oaks have been eliminated from the sites during the last decades so that an insufficient density of seed trees is present. The introduction of tree species that have previously not been present is possible on clear-cut sites or in large canopy openings that have been created by natural disturbances or harvest operations. Supplementary low-density planting might be a low-cost option to introduce the desired new species, in particular in the case of valuable (hardwood) species that increase the economic benefit of the forest land [34].

A change in tree species may be advised in regions where climate scenarios are predicting future site conditions that are difficult to tolerate by the presently existing set of tree species or where climate change reduces the competitive power of the respective species. Introduction of species (or provenances, see below) through assisted migration may be required when the predicted shift in species/provenance ranges exceeds the natural migration potential [35]. Niche modeling among other techniques offers to base the expected future tree species composition on transparent rules, even though it is possible to grow trees successfully outside of their natural habitat $[3,7$, 36]. Tree species effect extends also to the products that are derived from different species. Species that are used to produce long-lived products with a high potential for material substitution will have a higher greenhouse gas (GHG) mitigation effect than tree species used for short-lived products or for direct energy use. However, this aspect has received so far very little consideration in research and adaptive forest management.

Mixed species are recommended for many ecological reasons. They are more stress-resistant than single-species forests and in some instances are even more productive [37-39]. Tree species mixtures may reduce herbivory [40] either by reducing the availability of the preferred host species ("spatial concentration effect"), by representing physical or chemical barriers to foraging or dispersing herbivores by the accompanied non-host species, or by providing suitable habitats for the natural enemies of the respective forest pest. The effect of the species mixture depends not per se on tree species diversity but on the composition of the respective forest ecosystem.

Under otherwise identical site conditions and vulnerability to disturbances, highly productive trees accumulate carbon stocks faster in the biomass than slower growing trees. Given that soil carbon is widely composed of aboveground and belowground litterfall material, the cultivation of productive forests also affects the soil carbon pool. In addition, the decomposition of soil organic matter depends on the chemical quality of the litter input and can therefore influence soil carbon storage in the long run $[41,42]$. Replacing forests with easily degradable litter such as that of many deciduous species with species with more recalcitrant litter, i.e., conifers, is likely to have an impact on the rate of carbon cycling in the ecosystem. Evidence whether such effects lead to a lasting change of the size of the soil carbon pool is scattered and overall suggests a rather weak effect [43].

\section{Selection of Adaptive Ecotypes and Provenances}

Many expectations regarding the adaptation of forests to climate change and effects on the carbon cycle depend on the exploitation of the genetic variation within tree species. In many reforestation programs, the utilization of local seed sources has been regarded as the most efficient way to avoid maladaptation under stable environmental conditions. With changing climate, this assumption must be questioned. At present, a majority of tree species are still truly "wild" species with a genetic constitution that has not been altered by human activities. Even the most advanced breeding program worldwide - working on the third or fourth breeding cycle - contribute only to a small share to the market for forest reproductive material of the respective species. Two different improvement strategies are expected to affect the forest carbon cycle: first, the classical objective of tree improvement has been the increase of wood production for the provision of raw material and biomass. There is increasing demand for wood worldwide [68], and within each breeding cycle, the wood production can be increased between 5 and $15 \%$. Therefore, significant effects on the carbon cycle can be expected, in particular if the wood is more and more utilized for long-living wood products. Second, tree improvement programs can incorporate the resistance to stressful climatic conditions as a superior selection goal. This can include the utilization of nonlocal provenances better suited to future climate conditions as already shown for several tree species [44-46] or the selection of drought-adapted genotypes within breeding programs [47, 48]. Overall, the consideration of tree species' adaptation and adaptive potential to stressful abiotic 
conditions in tree improvement and reforestation schemes will allow continuing forest management with established economically valuable tree species. This will avoid the need to adopt silvicultural concepts that have little precedent. Successful genetic adaptation of currently highly productive forests to climate change would maintain or even increase their $\mathrm{CO}_{2}$ uptake capacity. The question however remains whether tree improvement measures can cope with the speed of climate change.

\section{Managing Disturbance Exposure}

Disturbance is an integral property of forest ecosystems. In consideration of a defined set of disturbance probabilities for a given forest stand, forest managers can modify the exposure with a set of adaptive silvicultural management strategies, or reduce the vulnerability through adjusting tree species composition, length of the production cycle and thinning, and prescribed burning operations [49,50]. A rather novel concern for the temperate zone is that the frequency of forest fires during drought periods in summer might increase. Of particular vulnerability are remote sites where fire fighting is difficult. Prescribed burning of organic surface materials has a long history in the USA and has been proposed for Europe as well $[51,52]$. The intention is to avoid any sudden release of large amounts of carbon into the atmosphere as a consequence of tree mortality. Climate change is believed to increase the frequency and magnitude of disturbances due to an increase in extreme events and by novel pressures such as newly invading pests and pathogens [49]. In Europe, disturbance is expected to increase in frequency and severity, with negative consequences on the carbon sink capacity of forest landscapes [53]. Adaptive management measures which increase resistance and resilience of forests can play an important role in mitigating carbon loss [54].

\section{Shortening the Production Cycle}

The increased productivity of forests in parts of the world such as Europe [55, 56], an increasing demand for small dimension conifer timber by the wood industry, and the increasing vulnerability of tall, mature forests towards disturbances highlight the potential utility of shorter production cycles. The argument of accruing less carbon in the standing biomass is countered by the more efficient utilization of high growth rates of young forests [57]. This strategy makes sense when the carbon cycle in long-living wood products is long enough to compensate for the decline in the standing stock of carbon in the living biomass [22]. However, it is difficult to generalize whether shorter production cycles are a viable strategy to reduce $\mathrm{CO}_{2}$ emissions to the atmosphere. A crucial factor is the local exposure to disturbances.

Shorter production cycles are changing the biogeochemical nutrient budgets and generally require a higher nutrient availability. This is partially attributable to the fact that a greater proportion of nutrient-rich sapwood per unit of total wood biomass is being removed. This demand can be met only on rather fertile sites or if nutrients can be supplied as fertilizer or wood ash [58]. Forest fertilization may provide the required nutrients but is rarely used in semi-natural forests. Field experiments have shown that fertilized forests gain a growth advantage in comparison to control plots and maintain this advantage for several decades [59]. However, fertilization can increase the production of greenhouse gases such as $\mathrm{N}_{2} \mathrm{O}$ in forest soils.

Foresters in North America and Central Europe are assisted by the fertilizing effect of anthropogenic deposition of nitrogen $[60,61]$.

\section{Decreasing Stand Density}

Thinning operations are an appropriate measure to reduce the production time of the desired tree dimensions. Increasing the growing space of trees accelerates their crown expansion and consequently their stem diameter growth. It increases tree health and vigor and thus reduces susceptibility to pests and pathogens. When trees have better access to site resources and can fix more carbon, they are less stressed and have more resources such as stored starch to respond to stress or disturbance. Consequently, well-thinned stands are less susceptible to secondary pests and pathogens that attack weakened or stressed individuals. Thinning also increases individual tree stability, which depends among other things on the extent and depth of the root system, the length of their crown, and the thickness of the stem. These tree attributes are promoted by thinning in young stands. Unstable forests are susceptible

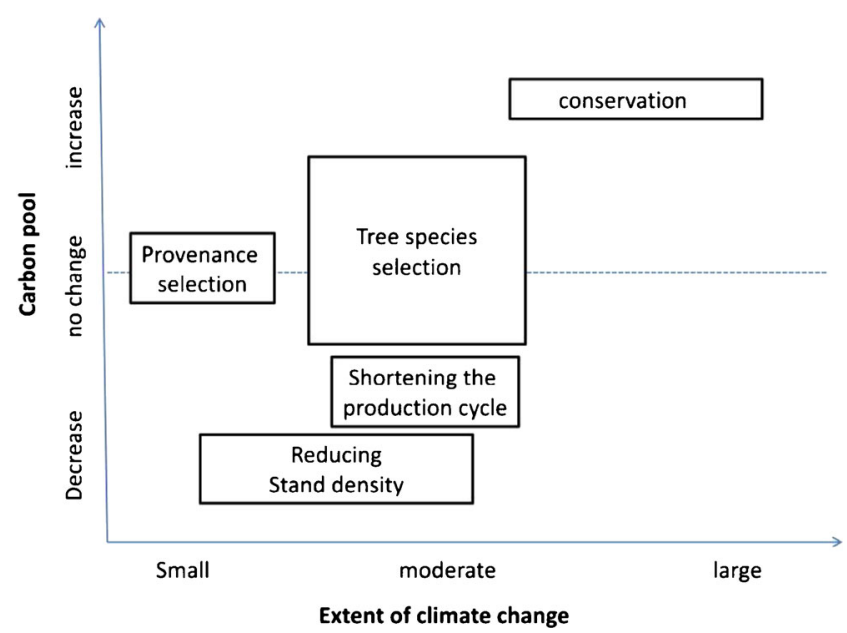

Fig. 1 Summary of the expected effect of measures of adapted forest management 
to storm damages, leading to the immediate release of $\mathrm{CO}_{2}$ that has been accumulated over several decades [62]. Owing to the recurrent interruptions of the canopy, thinned stands produce less biomass than unmanaged forests and accumulate less $\mathrm{CO}_{2}$ in the standing biomass. From an economical point of view, this effect is by far outweighed by the production of more valuable timber on the remaining forest stand (P38). With respect to GHG emissions, the main beneficial effect of thinning is the reduction of risk against disturbances such as storms. Direct effects such as an increased rate of greenhouse gas emissions from soils as consequence of higher soil temperatures in less dense forests are well based on ecological theory, but are small and can hardly be detected in field experiments $[63,64]$.

A second objective of thinning operations in the context of climate change is mitigating water stress. Climate change is expected to manifest itself in more frequent and prolonged drought periods during the growing season. In recently thinned stands, the water demand is reduced and it can be expected that particularly vulnerable tree species can cope with stressful site conditions more successfully [65]. In stands where trees have reoccupied the growing space following thinning, trees may be as much affected by drought as trees in unthinned stands; however, owing to their larger reserves, crowns, and root systems, they recover more quickly from drought [66]. However, it is not clear to what extent the results of these analyses of thinning effects on drought tolerance on a few conifer species can be extrapolated to other species.

\section{Adapted Forest Management in the Context of Changing Site Conditions and Societal Expectations}

Adaption of forest management to climate management is prominent on the agenda of forestry. Within the toolbox of forest management, many measures can be taken and they are to different degrees effective with respect to carbon sequestration (Fig. 1). Although the large-scale conservation of forest ecosystems at the expense of active management might be an effective way to accumulate a higher carbon pool in the long run, this scenario is unrealistic as long as the timber demand of an increasing human population needs to be met. The increasing mobilization of the wood resource together with climate change and age effects already has led to a slight decline in the carbon sink strength of forests in Europe [67].

Many measures of AFM are effective for a small or moderate climate change. There are strategies that increase the carbon pool. Changing tree species allows forest managers to mitigate the effects of moderate to large changes in climate and may lead to a substantial increase in the carbon pool, particularly when the newly introduced species leads to the accumulation of soil carbon. The reverse effect is also possible when the introduced tree species is less productive than its predecessor and accrues less carbon. The selection of specific provenances may be effective for a small change in climatic conditions. Given that there is no change in the tree species, no change in the carbon pool can be expected. Reducing the stand density for the sake of a sufficient water supply may enable the forest manager to keep the target tree species for the rotation period, but will rather decrease than increase the carbon pool. Also, shortening the production cycle may reduce the carbon pool, both in the biomass and the soil. Its main positive effect is the rapid provision of wood products.

Overall, the societal desires and demands on our forest ecosystems as well as economic realities of forest owners need to be considered and well-balanced with potential adaptation measures. The expectation of society that forest ecosystem serve multiple functions such as protection against natural hazards, provision of drinking water, a high biodiversity, and carbon sequestration are consequences of forest management decisions. Depending on the regional extent of climate change and the choice of the silvicultural strategy, the implementation of AFM will lead to an increase or decrease of the size of the carbon pool. In either way, AFM is an important tool for forest managers to maintain stable forests in order to ensure the provision of ecosystem services and to produce timber, which can be turned into long-living wood products that substitute for materials requiring a high-energy input upon their production.

Acknowledgments We are indebted to numerous colleagues. The structure of the article was inspired by a presentation of Tom Spies given at the IUFRO World Congress 2014 in Salt Lake City.

\section{Compliance with Ethics Guidelines}

Conflict of Interest Dr. Jandl, Dr. Bauhus, Dr. Bolte, Dr. Schindlbacher, and Dr. Schuler have no conflicts of interests to declare.

Human and Animal Rights and Informed Consent This article contains no studies with human or animal subjects performed by the author.

\section{References}

1. Pan Y, Birdsey RA, Fang J, Houghton R, Kauppi PE, Kurz WA, et al. A large and persistent carbon sink in the world's forests. Science. 2011;333:988-93.

2. Bolte A, Ammer C, Löf M, Nabuurs GJ, Schall P, Spathelf P. Adaptive forest management - a prerequisite of sustainable forestry in the face of climate change. In: Spathelf P, editor. Sustainable forest management in a changing world: European perspective. Managing forest ecosystems 19. Dordrecht: Springer; 2010. p. 115-39.

3. Hanewinkel M, Cullmann DA, Schelhaas M-J, Nabuurs G-J, Zimmermann NE. Climate change may cause severe loss in the economic value of European forest land. Nat Clim Chang. 2012;3:203-7. 
4. Ciais P, Reichstein M, Viovy N, Granier A, Ogé J, Allard V, et al. Europe-wide reduction in primary productivity caused by the heat and drought in 2003. Nature. 2005;437:529-33.

5. Zhang Z, Sun G, Fang X, Zha T, McNulty S, Chen J, et al. For Ecol Manag. 2013;300:33-42.

6. Allen CD, Macalady AK, Chenchouni H, Bachelet D, McDowell N, Vennetier $\mathrm{M}$, et al. A global overview of drought and heat-induced tree mortality reveals emerging climate change risks for forests. For Ecol Manag. 2010;250:660-84.

7. Lindner M, Fitzgerald JB, Zimmermann NE, Reyer C, Delzon S, van der Maaten E, et al. Climate change and European forests: what do we know, what are the uncertainties, and what are the implications for forest management? J Environ Manag. 2014;146:69-83.

8. Grüneberg E, Ziche D, Wellbrock N. Organic carbon stocks and sequestration rates of forest soils in Germany. Glob Chang Biol. 2014;20:2644-62. doi:10.1111/gcb.12558.

9. Luyssaert S, Ciais P, Piao SL, Schulze E-D, Jung M, Zaehle S, et al. The European carbon balance. Part 3: forests. Glob Chang Biol. 2010;16:1429-50.

10. Schulze E, Ciais P, Luyssaert S, Schrumpf M, Janssens IA, Thiruchittampalam B, et al. The European carbon balance. Part 4: integration of carbon and other trace-gas fluxes. Glob Chang Biol. 2010;16:1451-69.

11. Lundmark T, Bergh J, Hofer P, Lundström A, Nordin A, Poudel BC, et al. Potential roles of Swedish forestry in the context of climate change mitigation. Forests. 2014;5:557-78.

12. Taverna R, Hofer P, Werner F, Kaufmann E, Thürig, E. CO\$-Effekte der Schweizer Wald- und Holzwirtschaft. Szenarien zukünftiger Beiträge zum Klimaschutz. Bundesamt für Umwelt, 2007

13. Canadell JG, Raupach MR. Managing forests for climate change mitigation. Science. 2008;320:1456-7.

14. Malmsheimer R, Bowyer J, Fried J, Gee E, Izlar R, Miner R, et al. Managing forests because carbon matters: integrating energy, products, and land management policy. J For (Suppl). 2011;109:S7-51.

15. Harmon ME, Ferrell WK, Franklin JF. Effects of carbon storage of conversion of old-growth forests to young stands. Science. 1990;247: 699-702.

16. Ciais P, Schelhaas M, Zaehle S, Piao S, Cescatti A, Liski J, et al. Carbon accumulation in European forests. Nat Geosci. 2008;1:4259.

17. Luyssaert S, Schulze ED, Börner A, Knohl A, Hessenmöller D, Law $\mathrm{BE}$, et al. Old-growth forests as global carbon sinks. Nature. 2008;455:214-5.

18. Bellassen V, Luyssaert S. Managing forests in uncertain times. Nature. 2014;506:153-5.

19. Usbeck T, Wohlgemuth T, Dobbertin M, Pfister C, Bürgi A, Rebetez M. Increasing storm damage to forests in Switzerland from 1858 to 2007. Agric For Meteorol. 2010;150:47-55.

20. Spies TA, Hemstrom MA, Youngblood A, Hummel S. Conserving oldgrowth forest diversity in disturbance-prone landscapes. Conserv Biol. 2006;20:351-62.

21. Pietsch SA, Hasenauer H. Photosynthesis within large-scale ecosystem models. Chapter 19 in Laisk A; Nedbal L, Govindjce M. (Eds.) Photosynthesis in silico. Complexity from molecules to ecosystems, Springer, 2013; 441-464.

22. Lippke B, Oneil E, Harrison R, Skog K, Gustavsson L, Sathre R. Life cycle impacts of forest management and wood utilization on carbon mitigation: knowns and unknowns. Carbon Manag. 2011;2(3):30333.

23. Krug J, Koehl M, Kownatzki D. Revaluing unmanaged forests for climate change mitigation. Carbon Balance and Manag. 2012;7:1. doi:10.1186/1750-0680-7-11.

24. Böttcher H. Forest Management for climate change mitigation. $\mathrm{PhD}$ Thesis University Freiburg im Breisgau, 2007.
25. Searchinger TD, Hamburg SP, Melillo J, Chameides W, Havlik P, Kammen DM, et al. Fixing a critical climate accounting error. Science. 2009;326:527-8.

26. Lexer MJ, Jandl R, Nabernegg S, Bednar-Friedl, B. Forestry. Chapter 9 in Steininger KW, König M, Bednar-Friedl B, Kranzl L, Loibl W, Prettenthaler F. (Eds.), Economic evaluation of climate change impacts - development of a cross-sectoral framework and results for Austria, Springer, 2015; 145-165.

27. Mund M, Schulze E-D. Impacts of forest management on the carbon budget of European beech (Fagus sylvatica) forests. Allg Forst- und. 2006; 177(3-4):47-63.

28. Lindner M, Maroschek M, Netherer S, Kremer A, Barbati A, GarciaGonzalo J, et al. Climate change impacts, adaptive capacity, and vulnerability of European forest ecosystems. For Ecol Manag. 2010;259:698-709.

29. Knoke T, Stimm B, Ammer C, Moog M. Mixed forests reconsidered: a forest economics contribution on an ecological concept. For Ecol Manag. 2005;213(1):102-16.

30. Bolte A, Kampf F, Hilbrig L. Space sequestration below ground in old-growth spruce-beech forests - signs for facilitation? Front Plant Sci. 2013;4(322):11.

31. Pretzsch H, Schütze G, Uhl E. Resistance of European tree species to drought stress in mixed versus pure forests: evidence of stress release by inter-specific facilitation. Plant Biol. 2013;15:483-95.

32. Bauhus J, Puettmann KJ, Kühne C. (2013) Close-to-nature forest management in Europe: does it support complexity and adaptability of forest ecosystems? In: Messier, C., Puettmann, K.J. and Coates, K.D. (eds.): Managing forests as complex adaptive systems: building resilience to the challenge of global change. Routledge, The Earthscan forest library, pp. 187-213.

33. Pretzsch H. Diversity and productivity in forests: evidence from longterm experimental plots. Chapter 3 in Scherer-Lorenzen, M.; Körner, C. \& Schulze, E. (Eds.) Forest diversity and function: temperate and boreal systems, Springer Verlag, 2005; 41-64.

34. Saha S, Kohnle U, Brang P, Ehring A, Geisel J, Leder B, et al. Growth and quality of young oaks (Quercus robur and Q. petraea) grown in cluster plantings in Central Europe: a weighted meta-analysis. For Ecol Manag. 2012;283:106-18.

35. McKenney DW, Pedlar JH, Lawrence K, Campbell K, Hutchinson MF. Potential impacts of climate change on the distribution of North American trees. Bioscience. 2007;57(11):939-48.

36. Park A, Puettmann K, Wilson E, Messier C, Kamesa S, Dhar A. Can boreal and temperate forest management be adapted to the uncertainties of 21 st century climate change? Crit Rev Plant Sci. 2014;33:251-85.

37. Richards AE, Forrester DI, Bauhus J, Scherer-Lorenzen M. The influence of mixed tree plantations on the nutrition of individual species: a review. Tree Physiol. 2010;30:1192-208.

38. Pretzsch H, Dieler J, Seifert T, Rötzer T. Climate effects on productivity and resource-use efficiency of Norway spruce (Picea abies [L.] Karst.) and European beech (Fagus sylvatica [L.]) in stands with different spatial mixing patterns. Trees. Struct Funct. 2012;26: 1343-60.

39. Jactel H, Brockerhoff EG. Tree diversity reduces herbivory by forest insects. Ecol Lett. 2007;10:835-48.

40. Binkley D, Menyailo O. Gaining insights on the effects of trees on soils. In Binkley D. \& Menyailo O. (Eds.) vol 1 of Tree species effects on soils: implications for global change, Springer, 2005; 1-16.

41. Wang H. Effects of tree species mixture on soil organic carbon stocks and greenhouse gas fluxes in subtropical plantations in China. For Ecol Manag. 2013;300:4-13.

42. Menyailo OV, Hungate BA, Zech W. The effect of single tree species on soil microbial activities related to $\mathrm{C}$ and $\mathrm{N}$ cycling in the Siberian artificial afforestation experiment. Plant Soil. 2002;242:183-96.

43. Bolte A, Ammer C, Löf M, Madsen P, Nabuurs G-J, Schall P, et al. Adaptive forest management in central Europe: climate change 
impacts, strategies and integrative concept. Scand J For Res. 2009;24:473-82.

44. Wang T, Hamann A, Yanchuk Y, O’Neill G, Aiken S. Use of response functions in selecting lodgepole pine populations for future climates. Glob Chang Biol. 2006;12:2404-16.

45. Kapeller S, Lexer MJ, Geburek T, Hiebl J, Schueler S. Intraspecific variation in climate response of Norway spruce in the eastern Alpine range: selecting appropriate provenances for future climate. For Ecol Manag. 2012;271:46-57.

46. Pita P, Cañas I, Soria F, Ruiz F, Toval G. Use of physiological traits in tree breeding for improved yield in drought-prone environments. The case of Eucalyptus globules. Invest Agrar: Sist Recur For. 2005;14(3):383-93.

47. Dutkowski GW, Potts BM. Genetic variation in the susceptibility of Eucalyptus globulus to drought damage. Tree Genet Genomes. 2012;8:757-73.

48. Dale VH, Joyce LA, McNulty S, Neilson RP, Ayres MP, Flannigan MD, et al. Climate change and forest disturbances. BioSci. 2001;51: 723-34.

49. Seidl R, Schelhaas M-J, Rammer W, Verkerk PJ. Increasing forest disturbances in Europe and their impact on carbon storage. Nat Clim Chang. 2014;4:806-10.

50. Narayan C, Fernandes PM, van Brusselen J, Schuck A. Potential for $\mathrm{CO} 2$ emissions mitigation in Europe through prescribed burning in the context of the Kyoto Protocol. For Ecol Manag. 2007;251(3): 164-73.

51. Certini G. Effects of fire on properties of forest soils: a review. Oecologia. 2005;143:1-10.

52. Moore BA, Allard G. Abiotic disturbances and their influence on forest health: a review. Forest health and biosecurity working paper; 201.

53. Seidl R, Schelhaas M.-J, Lexer M. J. Unraveling the drivers of intensifying forest disturbance regimes in Europe. Global Change Biology, Blackwell Publishing Ltd, 2011;(17):2842-2852

54. Kahle HP (Ed.). (2008). Causes and consequences of forest growth trends in Europe: Results of the recognition project (Vol. 21). Brill.

55. Pretzsch H, Biber P, Schütze G, Uhl E, Rötzer T. Forest stand growth dynamics in Central Europe have accelerated since 1870. Nat Commun. 2014;5:4967. doi:10.1038/ncomms5967.

56. Cannell MG. Carbon sequestration and biomass energy offset: theoretical, potential and achievable capacities globally, in Europe and the UK. Biomass Bioenergy. 2003;24:97-116.
57. Fernández-Martínez M, Vicca S, Janssens IA, Sardans J, Campioli III SLM, Ciais FSC, et al. Nutrient availability as the key regulator of global forest carbon balance. Nat Clim Chang. 2014;4:471-6.

58. Johann K. Ergebnisse von Düngungsversuchen nach 30 Jahren ertragskundlicher Beobachtung. Ber FBVA. 2000;114:1-93.

59. de Vries W, Reinds GJ, Gundersen P, Sterba H. The impact of nitrogen deposition on carbon sequestration in European forests and forest soils. Glob Chang Biol. 2006;12:1151-73.

60. Schrumpf M, Kaiser K, Schulz E-D. Soil organic carbon and total nitrogen gains in an old growth deciduous forest in Germany. PLoS One. 2014;9:e89364.

61. Körner C. Slow in, rapid out — carbon flux studies and Kyoto targets. Science. 2003;300:1242-3.

62. Gathany MA, Burke IC. The effects of forest thinning practices and altered nutrient supply on soil trace gas fluxes in Colorado. Open J For. 2014;4:278-89.

63. Hakkenberg R, Churkina G, Rodeghiero M, Börner A, Steinhof A, Cescatti A. Temperature sensitivity of the turnover times of soil organic matter in forests. Ecol Appl. 2008;18:119-31.

64. Sohn J, Gebhardt T, Ammer C, Bauhus J, Häberle K-H, Matyssek R, et al. Mitigation of drought by thinning: short-term and long-term effects on growth and physiological performance of Norway spruce (Picea abies). For Ecol Manag. 2013;308:188-97.

65. Sohn J, Kohler M, Gessler A, Bauhus J. Interactions of thinning and stem height on the drought response of radial stem growth and isotopic composition of Norway spruce (Picea abies). Tree Physiol. 2012;32:1199-213.

66. Nabuurs G-J, Lindner M, Verkerk PJ, Gunia K, Deda P, Michalak R, et al. First signs of carbon sink saturation in European forest biomass. Nat Clim Chang. 2013;3:792-6.

67. Brang $\mathrm{P}$, Spathelf $\mathrm{P}$, Larsen JB, Bauhus J, Bonc ìna A, Chauvin C, et al. Suitability of close-to-nature silviculture for adapting temperate European forests to climate change. Forestry. 2014;87(Brang, P.; Spathelf, P.; Larsen, J. B.; Bauhus, J.; Bonc ìna, A.; Chauvin, C.; Drössler, L.; García-Güemes, C.; Heiri, C.; Kerr, G.; Lexer, M. J.; Mason, B.; Mohren, F.; Mühlethaler, U.; Nocentini, S):492-503.

68. Food and Agriculture Organization Of The United Nations 2009. State of the World's Forests 2009. Rome.

69. Holling C. Resilience and stability of ecological systems. Ann Rev Ecol Syst. 1973;4:1-23. 